\title{
A European carotenoid database to assess carotenoid intakes and its use in a five-country comparative study
}

\author{
M. E. O’Neill ${ }^{1}$, Y. Carroll ${ }^{2}$, B. Corridan ${ }^{2}$, B. Olmedilla ${ }^{3}$, F. Granado ${ }^{3}$, I. Blanco ${ }^{3}$, H. Van den Berg ${ }^{4}$, \\ I. Hininger ${ }^{5}$, A.-M. Rousell ${ }^{5}$, M. Chopra ${ }^{1}$, S. Southon ${ }^{6}$ and D. I. Thurnham ${ }^{1 *}$ \\ ${ }^{1}$ Northern Ireland Centre for Diet \& Health, University of Ulster, Coleraine BT52 1SA, UK \\ ${ }^{2}$ Nutritional Sciences, Department of Food Science and Technology, University College, Cork, Republic of Ireland \\ ${ }^{3}$ Unidad de Vitaminas, Seccion de Nutricion, Clinica Puerta de Hierro, San Martin de Porres 4, 28035 Madrid, Spain \\ ${ }^{4}$ TNO_CIVO Institute, PO Box 360 (Utrechsweg 48), 3700 AJ Zeist, The Netherlands \\ ${ }^{5}$ Laboratoire de Biochimie Micronutrients-Radicaux Libres, UFR des Sciences Pharmaceutiques et Biologiques, Domaine de \\ la Merci, 38700 La Tronche, France \\ ${ }^{6}$ Institute of Food Research, Colney, Norwich, UK
}

(Received 4 May 2000 - Revised 29 September 2000 - Accepted 26 October 2000)

\begin{abstract}
A food frequency questionnaire (FFQ) and carotenoid database with information on $\alpha$ - and $\beta$ carotene, lutein, lycopene and $\beta$-cryptoxanthin was prepared and used to compare the carotenoid intakes in five European countries: UK, Republic of Ireland, Spain, France and The Netherlands. Eighty, age- (25-45 years) and sex-matched volunteers were recruited in each of the five countries. A FFQ and carotenoid database was prepared of the most commonly consumed carotenoid rich foods in the participating countries and the information was used to calculate frequency and intake of carotenoid-rich foods. The median total carotenoid intake based on the sum of the five carotenoids, was significantly higher $(P<0.05)$ in France $(16.1 \mathrm{mg} / \mathrm{day})$ and lower in Spain $(9.5 \mathrm{mg} / \mathrm{day}$,) than the other countries, where the average intake was approximately $14 \mathrm{mg} /$ day. Comparison of dietary source of carotenoids showed that carrots were the major source of $\beta$-carotene in all countries except Spain where spinach was most important. Likewise, carrots were also the main source of $\alpha$-carotene. Tomato or tomato products, were the major source of lycopene. Lutein was mainly obtained from peas in Republic of Ireland and the UK, however, spinach was found to be the major source in other countries. In all countries, $\beta$ cryptoxanthin was primarily obtained from citrus fruit. Comparing the data with that from specific European country studies suggests that the FFQ and carotenoid database described in the present paper can be used for comparative dietary intake studies within Europe. The results show that within Europe there are differences in the specific intake of some carotenoids which are related to different foods consumed by people in different countries.
\end{abstract}

Carotenoids: Food frequency questionnaire: Diet

It is widely accepted that fruit and vegetables are 'healthy' foods and the consumption of five portions a day is recommended by several national and international authorities (Diet \& Health, 1989; WHO, 1990; Department of Health, 1994). The reason for this advice is that epidemiological data suggests that high intakes of fruit and vegetables are associated with a lower risk of chronic disease, especially cardiovascular disease (Gaziano et al. 1995) and cancer (Hennekens, 1986; Ziegler, 1989; Block et al. 1992). However, the active components in fruit and vegetables responsible for these effects are not certain. Interest has focused on the carotenoids because of their antioxidant properties and although there is a lack of consistent data in man suggesting that carotenoids have cancer-preventive effects, there is considerable experimental evidence that the major dietary carotenoids prevent or delay carcinogenesis at many sites (IARC, 1998). The carotenoids lutein and zeaxanthin have also been

\footnotetext{
Abbreviation: FFQ, food frequency questionnaire.

* Corresponding author: Professor D. I. Thurnham, fax + 442870 324965, email di.thurnham@ulst.ac.uk
} 
implicated in preventing age-related macular degeneration (Seddon et al. 1994) since they are the only carotenoids found in the retinal pigment epithelium in man and other primates, in contrast to other sites in the body where all carotenoids occur (Bone \& Landrum, 1985).

Europe contains people of many different cultures and dietary habits and there is evidence to suggest that wide differences in mortality from chronic diseases within Europe might be related to diet and the differences in intake of carotenoid-rich fruits and vegetables in the different countries. In the European cross-cultural epidemiological studies (MONICA), the intake of fruits and vegetables was found to be several fold higher in France (Jost et al. 1990) than in Northern Ireland (McClean et al. 1990) and the prevalence of cardiovascular disease three- to five-fold lower in France (Renaud \& de Lorgeril, 1993). Plasma concentrations of hydroxy-carotenoids (principally lutein) were found to be twice as high in individuals from Toulouse compared to those from Belfast and the incidence of cardiovascular disease was half of that reported in Belfast (Howard et al. 1996). However, to measure associations between carotenoid intake from diet and incidence of disease, a representative database of carotenoids in fruit and vegetables consumed in European countries is essential. The validity of all food intake data in terms of nutrient intakes is based on the availability and accuracy of food composition data. In both Europe and in the USA, most food composition tables at the time of this study provided only limited information on individual carotenoids in foods, with the exception of values for $\beta$-carotene or $\beta$-carotene equivalents (Gebhardt et al. 1982; Paul \& Southgate, 1994). At that time, a few databases were being developed in the USA (Forman et al. 1993; Mangels et al. 1993), however the composition and carotenoid content of many foods may well be different between USA and Europe. There was, therefore, a need for an accurate food composition database for the major carotenoids in foods customarily eaten in Europe.

As part of the Agro-Industry including Fisheries programme, several studies were undertaken in five European countries to evaluate the impact of fruit and vegetables or specific carotenoid supplements on certain biomarkers of chronic disease. Work from some of the studies within this project has already been published (Hininger et al. 1997; Collins et al. 1998; Granado et al. 1998; O'Neill \& Thurnham, 1998). For comparison of dietary intake of carotenoids in participating countries, a common food frequency questionnaire (FFQ) and a carotenoid database were prepared to calculate the carotenoid content of fruits and vegetables consumed most frequently in the five European countries UK, Ireland, Spain, France, and The Netherlands. The five most commonly occurring carotenoids in blood are $\beta$ carotene, lycopene, lutein, $\beta$-cryptoxanthin and $\alpha$-carotene. The objective of this paper is to describe the database of these five carotenoids compiled from the main vegetables and fruits consumed by the groups studied and describe the main food sources of the specific carotenoids consumed by the subjects in the respective countries.

\section{Subjects and methods}

Subjects

Healthy male and female volunteers aged $25-45$ years were enrolled in each of the centres, by local advertisement. Exclusion criteria included: post-menopausal women, anyone on prescribed medicine apart from oral contraceptives, serum retinol $<1.0 \mu \mathrm{mol} / \mathrm{l}$, heavy drinkers, abnormal lipid profile (total cholesterol $>6.8 \mathrm{mmol} / \mathrm{l}$; triacylglycerol $<4.0 \mathrm{mmol} / \mathrm{l}$; LDL:HDL $>5.0$ in conjunction with triacylglycerol $>2.3 \mathrm{mmol} / \mathrm{l})$. After screening for normal blood biochemistry, eighty volunteers (40 male and 40 female) were recruited from each centre. Ethical approval for the study was obtained within each of the institutions using relevant procedures.

\section{Food frequency questionnaires}

To determine the intake of carotenoids a dietary questionnaire was devised to include all commonly consumed, carotenoid-containing foods (mainly fruits and vegetables; O'Neill, 1997) and the main details are as follows. The FFQ was semiquantitative, containing 107 food items and was divided into seven sections: green-coloured, redorange-coloured, white-yellowish coloured vegetables, fruits, other products (mainly tomato products and soups), dairy products and other foods (liver and eggs). Volunteers were asked to quantify intake by tablespoons for vegetables, large, small or medium in terms of fruit portions. For eggs, milk and butter-margarine, intake was quantified as the number of items eaten per week, pints per day or grams per month respectively. The FFQs were administered with a set of instructions; for example, for the frequency of consumption per week they were asked to circle around appropriate numbers from 1 to 7 and if consumption was less frequent then to circle one of the following categories: once per fortnight, once per month, seldom or never. The individuals were asked to relate the questions to their dietary intake of foods over the three previous months. The selected frequency category for each food item was converted to a daily intake. For example, a response of 'two per week of a food item with a standard portion size of 60 g' was converted to $17 \cdot 14$ g per day.

For various reasons, FFQs were not completed by all the volunteers and the numbers collected in the specific centres were was follows: UK (Coleraine, Northern Ireland; 36 females, 35 males), Republic of Ireland (Cork; 36 females, 40 males), France (Grenoble; 37 females, 39 males), Spain (Madrid; 33 females, 37 males) and The Netherlands (Zeist; 39 females, 36 males). FFQ information was collected in all centres in the winter season and on a second occasion (May or June) in three countries UK (31 females, 33 males), Ireland (34 females, 41 males) and Spain (31 females, 29 males). FFQs were quantified using standard portion sizes as follows: UK (Crawley, 1992), Republic of Ireland (MAFF, 1993), France (local information, I. Hininger), Spain (local information, B. Olmedilla), and The Netherlands, (Hulshof et al. 1992). All the food weights calculated from the FFQs were converted to carotenoid values using the database shown in Table 1 by M.E.O. 
Table 1. Carotenoid database (The database values $(\mathrm{mg} / 100 \mathrm{~g}$ of food) are the average of values obtained from various sources (mainly from measurements done in five participating countries, references 1-10) with additional information from other sources (references 11-14) where no other European figures were available)

\begin{tabular}{|c|c|c|c|c|c|c|c|}
\hline \multirow[b]{2}{*}{ Food type } & \multirow[b]{2}{*}{ Latin name } & \multicolumn{5}{|c|}{ Carotenoids } & \multirow{2}{*}{$\begin{array}{c}\text { Literature } \\
\text { sources }\end{array}$} \\
\hline & & $\alpha$-Carotene & $\beta$-Carotene & Lutein & Lycopene & $\beta$-Cryptoxanthin & \\
\hline Apple & Pyrus malus & - & 0.022 & 0.051 & - & 0.010 & $1-8$ \\
\hline \multicolumn{8}{|l|}{ Apricot } \\
\hline Fresh & Prunus armeniace & 0.037 & 0.953 & 0.066 & - & 0.130 & $1-5$ \\
\hline Tinned & & 0.003 & 0.530 & 0.076 & - & 0.016 & $1,6,7,9$ \\
\hline Dried & & 0.009 & 0.827 & 0.067 & - & 0.038 & 1,9 \\
\hline $\begin{array}{l}\text { Artichoke } \\
\text { (globe-flower cooked) }\end{array}$ & Cynara scolymus & - & 0.059 & 0.275 & - & - & $2-5$ \\
\hline Asparagus (green, cooked) & Asparagus officinalis & - & 0.387 & 0.738 & - & - & $2-5$ \\
\hline Aubergine (white/yellow) & & - & 0.05 & 0.90 & - & - & 10 \\
\hline Avocado & Persea americana & 0.017 & 0.043 & 0.317 & - & 0.026 & $2-7,9$ \\
\hline Banana & Musa paradisica & 0.042 & 0.038 & 0.022 & - & - & $1-8$ \\
\hline $\begin{array}{l}\text { Baked beans } \\
\text { (tinned and reheated) }\end{array}$ & & - & 0.030 & 0.025 & 1.659 & - & 1 \\
\hline \multicolumn{8}{|l|}{ Beans } \\
\hline Broad (cooked) & Vicia faba & - & 0.406 & 0.654 & - & - & 1 \\
\hline Green (cooked) & Phaseolus vulgaria & 0.048 & 0.247 & 0.492 & - & - & $1-8$ \\
\hline Runner (cooked) & Phaseolus vulgaris & 0.000 & 0.369 & 0.632 & - & - & 1,8 \\
\hline Kidney & Phaseolus vulgaris & - & 0.00 & $0 \cdot 13$ & 0.00 & - & 10 \\
\hline Beansprouts & Phaseolus aureus & 0.020 & 0.020 & - & - & 0.020 & 9 \\
\hline Beet (leaves and stalks) & Beta vulgaris & - & 1.360 & 1.960 & - & - & $2-5$ \\
\hline $\begin{array}{l}\text { Beetroot (cooked and } \\
\text { pickled) }\end{array}$ & Beta vulgaris & - & 0.00 & - & 0.00 & - & 10 \\
\hline Blackberry & Rubus ulmifolius & 0.004 & 0.078 & - & - & 0.000 & 9 \\
\hline Blueberry & Vaccinium & 0.000 & 0.204 & - & - & - & 12 \\
\hline Broccoli (cooked) & Brassico oleracea & - & 0.944 & 1.596 & - & 0.024 & $1-7$ \\
\hline Brussel sprouts & Brassica oleracea & - & 0.324 & 0.669 & - & - & $1-8$ \\
\hline Cabbage & Brassica oleracea & & & & & & \\
\hline White (cooked) & & - & 0.016 & 0.099 & - & - & $2-5,8$ \\
\hline Green (cooked) & & - & 0.141 & 0.111 & - & - & 1,8 \\
\hline Red (raw) & & - & 0.006 & 0.017 & - & - & $2-8$ \\
\hline Red (cooked) & & - & 0.007 & 0.027 & - & - & 6,7 \\
\hline Savoy (cooked) & & - & 0.273 & 0.341 & - & - & 1 \\
\hline \multicolumn{8}{|l|}{ see also 'spring greens' } \\
\hline Cauliflower (cooked) & Brassica oleracea & - & 0.009 & 0.016 & - & - & $1-7$ \\
\hline Carrots (red-orange) & Dacus carrota & & & & & & \\
\hline Raw & & $2 \cdot 186$ & 7.975 & 0.271 & - & - & $1-7$ \\
\hline Tinned & & $3 \cdot 700$ & $9 \cdot 800$ & - & 0.000 & - & 11 \\
\hline Cooked & & $3 \cdot 274$ & $9 \cdot 422$ & 0.252 & - & - & $1-5$ \\
\hline Celery & Apium graveolens & & & & & & \\
\hline Green raw & & - & 0.570 & 0.860 & - & - & $2-5$ \\
\hline Cooked & & - & $1 \cdot 110$ & 1.335 & - & - & $2-5$ \\
\hline White & & - & 0.065 & 0.163 & - & - & $2-5$ \\
\hline Cherries & Prunus avium & 0.002 & 0.013 & 0.048 & 0.010 & 0.005 & $2-5$ \\
\hline Chicory leaf (raw, cooked) & Cichorium intybus & - & 0.000 & - & - & - & 8 \\
\hline Coleslaw & & 0.438 & 1.610 & 0.126 & - & - & 10 \\
\hline Courgette & Zucchini & - & 0.18 & 0.75 & 0.00 & - & 10 \\
\hline Cucumber (with skin) & Cucumis sativa & - & 0.231 & 0.570 & - & - & $1,6,7$ \\
\hline \multicolumn{8}{|l|}{ Dairy products } \\
\hline Butter & & - & 0.410 & - & - & - & $6-8$ \\
\hline \multicolumn{8}{|l|}{ Cheese } \\
\hline Yellow & & - & 0.119 & - & - & - & 6,7 \\
\hline \multirow{2}{*}{\multicolumn{8}{|c|}{ Milk }} \\
\hline & & & & & & & \\
\hline Whole & & - & 0.02 & - & - & - & 6,7 \\
\hline Semiskimmed & & - & 0.01 & - & - & - & 6,7 \\
\hline Skimmed & & - & - & - & - & - & \\
\hline Margarine & & - & 0.540 & - & - & - & $6-8$ \\
\hline Yogurt & & - & 0.013 & - & - & - & 6,7 \\
\hline \multicolumn{8}{|l|}{ Eggs } \\
\hline Whole & & - & 0.013 & 0.620 & - & - & 6,7 \\
\hline Yolk & & - & 0.029 & 1.576 & - & - & 6,7 \\
\hline Endives (cooked) & Cichorium endivia & - & 0.74 & - & - & - & 8 \\
\hline Fruit salad (home made) & & 0.00 & 0.02 & 0.05 & - & 0.05 & 10 \\
\hline Grapefruit & Citrus paradisi & & & & & & \\
\hline White/yellow & & 0.006 & 0.005 & 0.008 & - & 0.003 & $6-8$ \\
\hline Pink & & 0.000 & $1 \cdot 310$ & 0.00 & $3 \cdot 362$ & 0.000 & 11 \\
\hline
\end{tabular}


Table 1. continued

\begin{tabular}{|c|c|c|c|c|c|c|c|}
\hline \multirow[b]{2}{*}{ Food type } & \multirow[b]{2}{*}{ Latin name } & \multicolumn{5}{|c|}{ Carotenoids } & \multirow{2}{*}{$\begin{array}{l}\text { Literature } \\
\text { sources }\end{array}$} \\
\hline & & $\alpha$-Carotene & $\beta$-Carotene & Lutein & Lycopene & $\beta$-Cryptoxanthin & \\
\hline Grapes (white, with skin) & Vitis vinifera & - & 0.023 & 0.049 & - & - & $2-8$ \\
\hline Japanese Medlar & Eriobotyra japonica & - & 0.980 & - & - & 0.660 & $2-5$ \\
\hline Kiwi fruit & Actinida chinensis & - & 0.030 & 0.138 & - & - & $2-8$ \\
\hline Lemon & Citrus limonis & - & 0.000 & 0.008 & - & 0.014 & $2-7$ \\
\hline Leeks & Allium porrum & & & & & & \\
\hline Raw & & - & 0.069 & 0.121 & - & - & $1-5$ \\
\hline Cooked & & _- & 0.092 & 0.177 & _- & _- & $1-5$ \\
\hline Lettuce & Laticia sativa & & & & & & \\
\hline Butterhead & & - & 0.890 & 1.250 & - & - & $1-8$ \\
\hline Iceberg & & - & 0.071 & 0.167 & - & - & $1-7$ \\
\hline Liver & & - & 0.009 & - & - & - & 6,7 \\
\hline Mango (ripe, raw) & Mangifera indica & - & 1.30 & - & - & 0.054 & 11 \\
\hline Marrow (cooked and peeled) & Cucurbita pepo & - & 0.041 & 0.152 & - & 0.011 & $1-5$ \\
\hline Mayonnaise & & - & 0.042 & - & - & - & 8 \\
\hline Melon (yellow fleshed) & Cucumis melo & - & 0.03 & - & - & - & $2-5,8$ \\
\hline Mushroom (raw or cooked) & Agaricus bisporus & - & 0.00 & 0.00 & 0.00 & - & 10 \\
\hline Nectarine & Prunus persica nectarina & - & 0.05 & - & - & 0.03 & 9 \\
\hline Onion (cooked and peeled) & Allium cepa & - & 0.001 & 0.002 & - & - & $2-5$ \\
\hline Orange & Citrus sinensis & 0.016 & 0.025 & 0.092 & - & 0.266 & $1-8$ \\
\hline Orange (Mandarin) & Citrus reticulata & 0.016 & 0.152 & 0.106 & - & 1.309 & $1-8$ \\
\hline Orange (juice) & & 0.006 & 0.082 & 0.027 & - & 0.701 & $6-9$ \\
\hline Parsley (fresh) & Petriselinum crispum & - & 5.062 & 8.006 & - & - & $1,6,7$ \\
\hline Parsnips & Pastinaca sativa & - & 0.00 & 0.13 & 0.00 & - & 10 \\
\hline Peach & Prunus persica & 0.003 & 0.084 & 0.060 & - & 0.070 & $1-7$ \\
\hline \multicolumn{8}{|l|}{ Peas } \\
\hline Chick (cooked) & Pisum sativum & - & 0.000 & 0.440 & 0.000 & - & 10 \\
\hline Garden (cooked) & Pisum sativum & 0.000 & 0.548 & $1 \cdot 840$ & - & - & $1,6-8,10$ \\
\hline Pear & Pyrus communis & - & 0.010 & 0.061 & - & 0.003 & $2-7$ \\
\hline Pepper & Capsicum annum & & & & & & \\
\hline \multicolumn{8}{|l|}{ Green } \\
\hline Raw & & - & 0.248 & 0.567 & - & - & $1-7$ \\
\hline Cooked & & - & 0.399 & 0.700 & - & - & $1-5$ \\
\hline \multicolumn{8}{|l|}{ Red } \\
\hline Raw & & - & 0.48 & 0.29 & - & 0.25 & $2-5$ \\
\hline Cooked & & - & 0.77 & 0.39 & - & 0.37 & $2-5$ \\
\hline Pineapple (tinned) & Ananas comosus & 0.001 & 0.018 & 0.002 & - & 0.002 & 6,7 \\
\hline Pizza & & - & 0.34 & 0.23 & $4 \cdot 30$ & - & 14 \\
\hline Plum (raw, unpeeled) & Prunus domestica & - & 0.110 & - & - & - & 10 \\
\hline Plum (yellow, raw, peeled) & & - & 0.127 & 0.083 & - & - & $2-5$ \\
\hline Potatoes (cooked) & Solanum tuberosum & - & 0.00 & 0.06 & - & - & $2-5$ \\
\hline $\begin{array}{l}\text { Pumpkin (White-yellow, } \\
\text { cooked) }\end{array}$ & Cucurbita maxima & - & 0.49 & 0.63 & - & 0.06 & 6,7 \\
\hline Spinach (cooked) & Spinacea oleracea & - & 4.489 & $6 \cdot 265$ & - & - & $1-8$ \\
\hline Spring greens & Brassica oleracea & 0.000 & $2 \cdot 255$ & - & - & 0.023 & 9 \\
\hline Spring onions & Allium fistulosum & - & 0.142 & 0.255 & - & - & 1 \\
\hline Squash (cooked and peeled) & Cucurbita pepo & - & 0.05 & 0.135 & - & - & 1 \\
\hline Strawberries & Fragaria elatior & - & 0.008 & 0.017 & - & - & $1-7$ \\
\hline $\begin{array}{l}\text { Sweetcorn or corn on cob } \\
\text { (frozen and cooked) }\end{array}$ & Zea mays & 0.033 & 0.024 & 0.819 & - & - & 1 \\
\hline Tomatoes & Lycopersicon esculentum & & & & & & \\
\hline Raw & & - & 0.608 & 0.077 & $2 \cdot 718$ & - & $1-8$ \\
\hline Cooked & & - & 0.658 & 0.120 & 3.703 & - & 1 \\
\hline Tinned and reheated & & - & 0.258 & 0.116 & $5 \cdot 613$ & - & 1 \\
\hline Chutney & & - & 0.49 & 0.00 & 5.50 & - & 10 \\
\hline Juice & & - & 0.423 & 0.030 & $9 \cdot 675$ & - & $8,11,13$ \\
\hline Ketchup & & - & $5 \cdot 000$ & $0 \cdot 210$ & $9 \cdot 900$ & - & 6,7 \\
\hline Puree & & - & 0.480 & 0.110 & 14.57 & - & $2-5$ \\
\hline Soup & & - & 0.27 & 0.005 & 13.66 & - & 1,13 \\
\hline Turnips (raw) & & - & 0.072 & 0.00 & - & - & 6,7 \\
\hline \multicolumn{8}{|l|}{ Vegetable soup } \\
\hline Green (minestrone) & & 0.21 & 0.92 & 0.15 & 1.48 & - & 13 \\
\hline Orange & & - & 1.54 & 0.04 & - & - & 10 \\
\hline Vegetables (Mixed) & & 1.045 & 4.505 & 1.035 & - & - & 1 \\
\hline Watercress & Nasturtium officinale & - & 5.919 & $10 \cdot 713$ & - & - & 1 \\
\hline Watermelon (peeled ripe) & Citrillus vulgaris & 0.000 & $0 \cdot 154$ & 0.027 & 3.477 & 0.062 & $2-7$ \\
\hline
\end{tabular}

Superscript numbers 1-11 indicate the following sources of information: 1. Hart \& Scott (1995); 2-5. Granado et al. 1992; Olmedilla et al. (1993, 1995, 1996); 6,7. Heinonen et al. (1988; 1989); Ollilainen et al. (1988; 1989); 8. Vollebregt \& Feskens (1993); 9. Holland et al. (1991); 10. in house methods; 11. Mangels et al. (1993); 12. Burlingame (1993); 13. Tonucci et al. (1995); 14. Smith C, Beecher G \& Buzzard M, unpublished data.

-, There were no carotenoid values reported for these foods. 


\section{Carotenoid database}

At the start of this study there was only a limited amount of information available on the carotenoid composition of foods within existing tables, making it necessary to compile a carotenoid database which could be used within Europe. Data from a variety of sources (Table 1) were added to the computerised dietary analysis programme Comp-Eat 4 (Nutrition Systems, London, UK) to analyse the FFQ. For $\beta$-carotene, information was already available within the database but this was updated from the different sources at the same time as adding the values for lutein (including zeaxanthin), lycopene, $\beta$-cryptoxanthin and $\alpha$-carotene. Zeaxanthin was not quantified separately and where values were available, they were included with lutein. Data was collected from a variety of sources (shown in Table 1). Where more than one carotenoid value was available for a food, an average of the values was taken as representative of the composition.

\section{Statistical analysis}

The concentrations of individual carotenoid intakes of subjects studied for all five European countries were found to be skewed; therefore, medians and interquartile ranges (IQR) are shown in the tables but intake values were logtransformed for statistical analysis.

\section{Results}

The carotenoid database shown in Table 1, was compiled to assess the dietary intakes of the five carotenoids ( $\beta$ carotene, lutein, lycopene, $\beta$-cryptoxanthin and $\alpha$-carotene) for the subjects recruited in the respective centres in Spain (Madrid), France (Grenoble), The Netherlands (Zeist), Republic of Ireland (Cork) and UK (Coleraine, Northern Ireland). The information was compiled using available data from within Europe but on occasions when values were not available, American values were included (Mangels, 1993).

Table 2 shows the median (interquartile range) dietary carotenoid intakes for the subjects in all participating countries in the winter season. The sum of these five dietary carotenoids was used as an indicator of the total carotenoid intake (total). No significant difference in the dietary intake of these carotenoids was observed between males and females, so the data were combined. The data suggest that the French had a significantly higher $(P<$ $0.05)$ median intake of total carotenoids $(16.1 \mathrm{mg} / \mathrm{d})$ than all other participating countries. The UK, Republic of Ireland and The Netherlands all had similar total dietary carotenoid intakes, $14.4,14.5$ and $13.7 \mathrm{mg} / \mathrm{d}$ respectively and the Spanish had the lowest intake $(9.5 \mathrm{mg} / \mathrm{d}, P<$ $0 \cdot 05)$. The French had the highest intake of both $\beta$-carotene and lycopene with the Spanish having the lowest intake of all carotenoids, except lutein (+ zeaxanthin) and $\beta$ cryptoxanthin (Table 2). Median intakes of individual carotenoids calculated from the FFQs ranged from approximately 3 to $6 \mathrm{mg}$ for $\beta$-carotene, 1.5 to $3.2 \mathrm{mg}$ for lutein (+ zeaxanthin), 1.6 to $5 \mathrm{mg}$ for lycopene, 0.3 to $1.2 \mathrm{mg}$ for $\alpha$-carotene and 0.5 to $1.4 \mathrm{mg}$ for $\beta$-cryptoxanthin consumed per day by the volunteers.

The same FFQ was also used in May (UK, Republic of Ireland) and June (Spain) and the same subjects were asked to indicate their consumption of fruit and vegetables in the previous 3 months. There were no seasonal differences in the median (IQR, mg/d) total intakes of carotenoids in the UK $(14 \cdot 6,10 \cdot 6,17 \cdot 7)$, Republic of Ireland $(13 \cdot 9,9 \cdot 0,19 \cdot 4)$ or Spain $(11.3,8 \cdot 3,14 \cdot 4)$. Likewise, there were no seasonal or sex differences for any of the individual carotenoids (data not shown) except for lycopene $(2 \cdot 7,1.4,4 \cdot 5)$ and $\beta$ cryptoxanthin $(0.41,0.23,0.64)$ in Spain where intakes of these nutrients for the sexes combined, were higher or lower respectively $(P<0.001$, Paired $t$ test $)$ in the summer than the winter months (compare with Table 2).

Table 3 shows the two main foods contributing to the intake of the individual carotenoids by the volunteers in the different European countries. Carrots are the richest source of $\beta$-carotene in the European diet and are generally the principal dietary source of $\beta$-carotene contributing from $24 \%$ (Spain) to $60 \%$ (Republic of Ireland) of the total intake. Only in Spain where carrots were not consumed in such large amounts did another food, spinach, make the major contribution to dietary $\beta$-carotene. Spinach was also the second most important food source of $\beta$-carotene in France and The Netherlands but in other countries, tomato products (Republic of Ireland) and soups (UK) were the second most important source of $\beta$-carotene.

Carrots, or food products containing carrots such as coleslaw, were also the main source of $\alpha$-carotene in all five countries, contributing over $80 \%$ in four countries and $60 \%$ in Spain. Citrus fruit (oranges and tangerines)

Table 2. Comparison of carotenoid intakes $(\mathrm{mg} / \mathrm{d})$ in adults in five European countries

(Data are medians and interquartile ranges)

\begin{tabular}{|c|c|c|c|c|c|c|c|c|c|c|c|c|}
\hline & \multicolumn{2}{|c|}{$\beta$-Carotene } & \multicolumn{2}{|c|}{ Lutein (+Zeaxanthin) } & \multicolumn{2}{|c|}{ Lycopene } & \multicolumn{2}{|c|}{$\alpha$-Carotene } & \multicolumn{2}{|c|}{$\beta$-cryptoxanthin } & \multicolumn{2}{|c|}{ Total Carotenoids* } \\
\hline & dian & e & $a n$ & Rar & ec & Range & Median & $\mathrm{Ra}$ & Median & $\mathrm{Ra}$ & $\overline{l e d}$ & $\mathrm{R}$ \\
\hline & .96 & & 25 & & $a_{1.64}$ & & $4^{\mathrm{a}} 0.29$ & & $a_{1.36}$ & 0 & $y$ & \\
\hline 6 & 84 & $3 \cdot 8$ & ) & & ${ }^{c} 4.75$ & & $1^{\circ} 0.74$ & & ${ }^{b} 0.45$ & & 8 & \\
\hline $\mathrm{k}$ & .55 & 3.6 & s & & ${ }^{c} 5.01$ & & $3^{c_{1} .04}$ & & ${ }^{\circ} 0.99$ & 0.3 & & \\
\hline & ${ }^{c} 5.16$ & 3.4 & & & ${ }^{c} 4.43$ & & $3^{{ }^{c}} 1.23$ & & ${ }^{c} 0.78$ & & & \\
\hline The Netherland & $b_{4} \cdot 35$ & $2.93-5.7$ & $c_{2} \cdot 01$ & 3.04 & ${ }^{c} 4.86$ & $2.79-7.53$ & $3^{a} 0.68$ & -0.90 & ${ }^{\circ} 0.97$ & 0.5 & $5^{c} 13.71$ & $9.98-17.7$ \\
\hline
\end{tabular}

Food frequency questionnaires were used to quantify dietary intakes of the different foods contributing specific carotenoids to the diet. Analysis of the carotenoid composition was obtained using a modified database attached to the Comp-Eat 4 dietary analysis programme.

a,b,c Superscripts indicate differences between country-means measured using ANOVA on log-transformed data followed by Scheffe test $(P<0.05)$

* Total carotenes $=\beta$-carotene + lutein + lycopene $+\alpha$-carotene $+\beta$-cryptoxanthin. 
Table 3. Major foods contributing to carotenoid intake in adults in the five European countries

(Table shows the percentage contribution of individual food items to the total intake of each of the five carotenoids in parentheses)

\begin{tabular}{|c|c|c|c|c|c|}
\hline & $\begin{array}{l}\text { France (Grenoble) } \\
\text { Name }(\%)\end{array}$ & $\begin{array}{c}\text { Republic of Ireland (Cork) } \\
\text { Name (\%) }\end{array}$ & $\begin{array}{l}\text { UK (Coleraine) } \\
\text { Name }(\%)\end{array}$ & $\begin{array}{c}\text { The Netherlands (Zeist) } \\
\text { Name (\%) }\end{array}$ & $\begin{array}{l}\text { Spain (Madrid) } \\
\text { Name }(\%)\end{array}$ \\
\hline \multirow[t]{2}{*}{$\beta$-carotene } & Carrots (38) & Carrots (60) & Carrots (53) & Carrots (42) & Spina \\
\hline & Spinach (14) & Tomato products (13) & Soup & Spinac & Carrot \\
\hline \multirow[t]{2}{*}{ Lutein } & Spinach (31) & Peas (19) & Peas (36) & Spinach (30) & Spinach (34) \\
\hline & Lettuce (8) & Broccoli (16) & Broccoli (8) & Broccoli (10) & Lettuce (16) \\
\hline \multirow[t]{2}{*}{ Lycopene } & Tomatoes (25) & Tomatoes, canned (23) & Tomatoes (21) & soup (29) & Tomatoes (55) \\
\hline & Tomatoes canned (16) & Tomato soup (17) & Tomatoes, canned (20) & Tomatoes (16) & Tomato puree (42) \\
\hline \multirow[t]{2}{*}{$\alpha$-carotene } & Carrots (82) & Carrots (90) & Carrots (88) & Carrots (87) & Carrots (60) \\
\hline & Oranges (6) & Coleslaw (5) & Coleslaw (6) & Oranges (5) & Tangerines (17) \\
\hline \multirow[t]{2}{*}{$\beta$-cryptoxanthin } & Orange juice (50) & Oranges (42) & Orange juice (45) & Tangerines (41) & Tangerines (53) \\
\hline & Oranges $(30)$ & Tangerines (28) & Oranges (26) & Orange juice (33) & Oranges (38) \\
\hline
\end{tabular}

provided a small contribution to $\alpha$-carotene intake in Spain, France and The Netherlands.

Spinach was the main contributor to dietary lutein in France, The Netherlands and Spain and peas were the main contributor in Republic of Ireland and UK, while lettuce (France and Spain) and broccoli (Republic of Ireland, UK and The Netherlands) were second most important (Table 3).

The three most important food sources of lycopene are shown in Table 3. Differences between countries were seen only in respect of lycopene intake associated with pizza consumption. In Spain unlike the other four countries, pizza consumption was a minor contributor to lycopene intake, and fresh tomatoes and tomato puree in other dishes were the principal food sources. In the second FFQ, tomato consumption continued to contribute similar amounts of lycopene to the diet of young Spanish men and women but lycopene intake increased because of the greater consumption of water melon which contributed an additional $23 \%$ to the diet at that time. There were no apparent differences in the food consumption patterns affecting lycopene in the UK or Ireland between these two seasons.

As expected, dietary $\beta$-cryptoxanthin was provided mainly by citrus fruit or fruit juices. Oranges (Ireland), tangerines (Spain and The Netherlands) or orange juice (UK and France) were the principal sources in the respective countries and in one form or another, these foods contributed $70 \%$ or more in the different countries. Consumption of $\beta$-cryptoxanthin-containing foods was significantly smaller in April to June than in the winter season in Spain, mainly due to a fall in the consumption of tangerines, but there was no apparent change in dietary habits in the UK or Republic of Ireland.

\section{Discussion}

European data on the $\alpha$-carotene, $\beta$-carotene, lutein, lycopene and $\beta$-cryptoxanthin content of commonly consumed vegetables and fruits and foods containing the same nutrients, were used to compile a European food composition database to determine comparative intakes of these carotenoids in matched groups of young adults in five European countries. Dietary intakes of fruit- and vegetablecontaining foods were obtained using the same FFQ translated into the respective languages and the information was related to dietary habits at the same time of year. Food portion sizes were converted to weights using locally available knowledge or referenced information as indicated, and carotenoid intakes determined from the common database (Table 1). Both the questionnaire and carotenoid database included a wide range of foods, making it possible to estimate the dietary intake from a wide choice of foods. Using this standardised procedure, the French were found to have the highest intake of carotenoids (a median value of $16 \cdot 1 \mathrm{mg} / \mathrm{d}$, attributable to a high consumption of carrots, fresh tomatoes and spinach). The Spanish had the lowest intake $(9.5 \mathrm{mg} / \mathrm{d})$, and the UK, Irish and Dutch had similar carotenoid intakes of approximately $14 \mathrm{mg} / \mathrm{d}$.

In two previous studies in Spain (Granado et al. 1996) and the UK (Scott et al. 1996) both found very similar foods were the major sources of carotenoids in the diet. However, the estimated dietary intake of carotenoid-rich foods by the FFQ method is high in comparison to that obtained by those and other workers. Granado et al. (1996) used an open-questionnaire method and household measurements to assess of 234 foods items consumed over 1 week in over 21000 private Spanish households, and reported a mean carotenoid intake of $3.5 \mathrm{mg} / \mathrm{d}$. However, this value excludes processed foods (frozen and canned), sauces (eg ketchup) and bottled juices, which will make a significant contribution to carotenoid intakes but these foods alone do not explain the difference. Likewise, Scott et al. (1996) who used $16 \mathrm{~d}$ weighed records from 162 women 50-62 years, obtained a figure of $4.2 \mathrm{mg} / \mathrm{d}$ for the intake of lutein, lycopene and $\beta$-carotene combined. This value does not include the contribution from two of the minor carotenoids, $\alpha$-carotene and $\beta$-cryptoxanthin and the subjects were older than those in the AAIR study (discussed later), but again, these factors are unlikely to explain the difference.

One of the factors which may account for the high intakes observed using the FFQ method, may be a tendency to overestimate the consumption of vegetables and fruits when presented with a long list of choices (Haraldsdottir, 1993). When actual consumption is monitored, very few vegetables and fruits account for most of the carotenoid intake. Scott et al. (1996) reported that 24 vegetable items provided $98.5 \%$ and five fruit types contribute $63 \%$ of calculated $\beta$-carotene equivalents. Likewise, 15 vegetables and 14 fruits accounted for 
$95 \%$ of the total fruit and vegetable consumption in Spain (Granado et al. 1996). However, the FFQ designed for the AAIR study contained 107 carotenoid-containing food items in order to provide a common questionnaire for all the countries. It has been suggested that the problem of over-reporting in field questionnaires can be corrected by incorporating a 'global' question (Haraldsdottir, 1993) and if total intakes appear excessive they may be modified by scaling individual food quantities to a collective value such as the total intake of cooked vegetables (Ocke et al. 1997). No such correction was done in the AAIR study and while such a procedure might be appropriate for $\beta$-carotene in one environment (Ocke et al. 1997), difficulties are envisaged in trying to apply such a correction to all the carotenoids in different environments and for subjects with different dietary patterns. Carotenoids in fruits are generally more bioavailable than those in vegetables but even different vegetables (e.g. leaf, flower and seeds) show different bio-availabilities (van het Hof et al. 1999).

The results of the present study are however, comparable with some other published data on FFQ carotenoid intakes. Studies of Willett et al. (1988) and Enger et al. (1995) reported FFQ intake data for total carotenoids $(\beta$-carotene, lutein + zeaxanthin, lycopene, $\alpha$-carotene and $\beta$-cryptoxanthin) of 13.3 and $14.2 \mathrm{mg} / \mathrm{d}$ respectively and Friis et al. (1997) calculated the $\beta$-carotene intake of women to be $7 \cdot 3 \mathrm{mg} / \mathrm{d}$.

Recently Carroll et al. (1999) used the carotenoid intakes of the same subjects reported in this study, to compare with information obtained from dietary records estimated with the aid of a photographic atlas. The atlas technique gave estimates for the carotenoid intake which were two- to three-fold lower than those obtained using the FFQ. However the authors also reported that the carotenoid intakes calculated from the FFQ data gave higher results $(21.7 \mathrm{mg} / \mathrm{d})$ than those described in this paper $(15.5 \mathrm{mg} / \mathrm{d})$. After a careful examination of the techniques used by our two groups to calculate the data, the most likely source of the different results must be attributable to a difference in the carotenoid database. Both groups used the same sources of information on portion sizes (Crawley, 1992; MAFF, 1993) and both groups used the same sources of information on carotenoid composition but, where several groups have reported information on the same food, the average values are shown in the database (Table 1). It would appear that the average values reported in this paper are lower than those used by Carroll et al. (1999).

Goldbohm et al. (1998) recently reported carotenoid intakes of approximately 3000 Dutch men and women aged 55-69 years calculated from a semiquantitative FFQ. Results for mean $\alpha$-carotene $(0.69,0.71)$ and lutein $(2.55$, $2.48 \mathrm{mg} / \mathrm{d}$ ) intakes in men and women respectively are almost identical to those shown in Table 2. However, $\beta$ carotene $(2.98,2.97 \mathrm{mg} / \mathrm{d})$ and lycopene $(1.05,1.33 \mathrm{mg} / \mathrm{d})$ were both lower than those of the EC study. The Dutch subjects were older (55-69) than those in the EC study (25-45 years) and the Dutch subjects included both smokers and non-smokers. Smoking is known to be associated with lower carotenoid intakes in the UK (Margetts \& Jackson, 1996). In addition, in the case of lycopene, tomato juice (Dutch) and tomato soup (EC study) were the main food sources and not only does tomato soup have higher lycopene content than tomato juice (Table 1), but also the database used by the Dutch group report lower levels for the lycopene content of tomato juice than those used in the present study. Age can also influence carotenoid intake and Carroll et al. (1999) reported that $\beta$-carotene and lycopene intakes were 36 and $58 \%$ lower in the older population respectively. Several of the other European studies are done on older populations and old age may be an additional factor explaining the lower carotenoid intakes (Scott et al. 1996; Bingham et al. 1997; Van Rossum et al. 2000 ). Thus the age and the inclusion of smokers may be additional reasons for some of the lower $\beta$-carotene and lycopene intakes reported in these and other studies but a combination of factors including the time of the studies as well as differences in the databases and correction factors used may also have contributed.

In summary, many factors will influence the apparent carotenoid intake of subjects in different population groups including subject-related factors as well as the methodology used to quantify the intakes. The FFQ itself probably overestimates carotenoid intakes but information on contributions from different foods to the overall carotenoid intake is qualitatively similar to that of other more accurate methods such as weighed dietary records. The most important feature of these results however, is that they provide comparative inter-country data on dietary carotenoids from comparably-aged subjects using the same methodology, that is a common FFQ and the same carotenoid database.

\section{Acknowledgements}

This study was funded by the European Union under grant number AIR2-CT93-0888.

\section{References}

Bingham SA, Gill C, Welch A, Cassidy A, Runswick SA, Oakes S, Lubin R, Thurnham DI, Key TJA, Roe DA, Khaw KT \& Day NE (1997) Validation of dietary assessment methods in the UK arm of EPIC using weighed records, and 24-hour urinary nitrogen and potassium and serum vitamin $\mathrm{C}$ and carotenoids as biomarkers. International Journal of Epidemiology 26, Suppl. 1, S137-S151.

Block G, Patterson B \& Subar A (1992) Fruit, vegetables, and cancer prevention, A review of epidemiological evidence. Nutrition Cancer 18, 1-30.

Bone RA \& Landrum JT (1985) Preliminary identification of the human macular pigment. Vision Research 25, 1531-1535.

Burlingame B (1993) Carotenoid content of New Zealand foods. In The carotenoid content of foods with special reference to developing countries [CE West and EJ Poortvliet, editors]. Arlington, VA: Vitamin A Field Support Project (VITAL).

Carroll YL, Corridan BM \& Morrissey PA (1999) Carotenoids in young and elderly healthy humans: dietary intakes, biochemical status and diet-plasma relationships. European Journal of Clinical Nutrition 53, 644-653.

Collins AR, Olmedilla B, Southon S, Granado F \& Duthie SJ (1998) Serum carotenoids and oxidative damage in human lymphocytes. Carcinogenesis 19, 2159-2162.

Crawley H (1992) Food Portion Sizes. Ministry of Agriculture, Fisheries and Food, London: HMSO. 
Department of Health (1994) Nutritional aspects of cardiovascular disease. Report of the cardiovascular review group, Committee on Medical Aspects of Food Policy. Report on Health and Social Subjects 46. London: HMSO.

Diet \& Health (1989) Implications for reducing chronic disease. Committee on Diet and Health, Food and Nutrition Board Washington: National Academy Press.

Enger S, Longnecker M, Shikany J, Swenseid M, Chen M, Harper J \& Haile R (1995) Questionnaire assessment of intake of specific carotenoids. Cancer Epidemiology Biomarkers \& Prevention 4, 201-205.

Forman MR, Lanza E, Yong L-C, Holden JM, Graubard BI, Beecher GR, Melitz M, Brown ED \& Smith JC (1993) The correlation between two dietary assessments of carotenoid intake and plasma carotenoid concentrations: application of a carotenoid food-composition. American Journal of Clinical Nutrition 58, 518-524.

Friis S, Kjaer K, Stripp C \& Overvad K (1997) Reproducibility and relative validity of a self-administered food frequency questionnaire applied to younger women. Journal of Clinical Epidemiology 50, 303-311.

Gaziano JM, Manson JE, Branch LG, Colditz GA, Willett WC \& Buring JE (1995) A prospective study of consumption of carotenoids in fruits and vegetables and decreased cardiovascular mortality in the elderly. Annals of Epidemiology 5, 255260.

Gebhardt SE, Cutrufelli R \& Matthews RH (1982) Composition of foods: fruits and fruit juices - raw, processed, prepared. Washington DC: US Dept of Agriculture. Handbook No. 8-11.

Goldbohm RA, Brants HAM, Hulshof KFAM \& van den Brandt PA (1998) The contribution of various foods to intake of vitamin A and carotenoids in the Netherlands. International Journal for Vitamin and Nutrition Research 68, 378-383.

Granado F, Olmedilla B, Blanco I \& Rojas-Hidalgo E (1992) Carotenoid composition of raw and cooked Spanish vegetables. Journal of Agricultural Chemistry 40, 2135-2140.

Granado F, Olmedilla B, Blanco I \& Rojas-Hidalgo E (1996) Major fruit and vegetable contributors to the main serum carotenoids in the Spanish diet. European Journal of Clinical Nutrition 50, 246-250.

Granado F, Olmedilla B, Gil-Martinez E \& Blanco I (1998) Lutein ester in serum after lutein supplementation in human subjects. British Journal of Nutrition 80, 445-449.

Haraldsdottir J (1993) Minimizing error in the field: quality control in dietary surveys. European Journal of Clinical Nutrition 47, S19-S24.

Hart DJ \& Scott KJ (1995) Development and evaluation of an HPLC method for the analysis of carotenes in vegetables and fruits in the UK. Food Chemistry 54, 101-111.

Hennekens CH (1986) Micronutrients and cancer prevention. New England Journal of Medicine 315, 1288-1289.

Heinonen MI, Ollilainen V, Linkola E, Varo P \& Koivistoinen P (1988) Carotenoids and retinoids in Finnish foods: Dietary fats. Journal of Food Composition and Analysis 1, 334-340.

Heinonen MI, Ollilainen V, Linkola EK, Varo PT \& Koivistoinen PE (1989) Carotenoids in Finnish foods: Vegetables, fruits, and berries. Journal of Agricultural and Food Chemistry 37, 655-659.

Hininger I, Chopra M, Thurnham DI, Laporte F, Richard M-J, Favier A \& Roussel A-M (1997) Effect of increased fruit and vegetable intake on the susceptibility of lipoprotein oxidation in smokers. European Journal of Clinical Nutrition 51, 601-606.

Holland B, Unwin ID \& Buss DH (1991) Vegetables, herbs and spices. First supplement to McCance \& Widdowson's The Composition of Foods. Cambridge: Royal Society of Chemistry.

Howard AN, Williams NR, Palmer CR, Cambou JP, Evans AE,
Foote JW, Marques-Vidal P, McCrum EE, Ruidavets JB, Nigdikar SV, Rajput-Williams J \& Thurnham DI (1996) Do hydroxy-carotenoids prevent coronary heart disease? A comparison between Belfast and Toulouse. International Journal for Vitamin and Nutrition Research 66, 113-118.

Hulshof K, Van der Heijden LJM \& Donders-Engelen M (1992) Maten, geivieliten en code nummers (Measurements, weights and code numbers). TNO report 92.003. Zeist, The Netherlands: TNO Nutrition and Food Research Institute.

IARC Working Group (1998) Carotenoids. Lyon: WHO International Agency for Research on Cancer.

Jost JP, Simon C, Nuttens MC, Bingham A, Ruidavets JB, Cambou JP, Arveiler D, Lecerf JM, Schlienger JL \& DousteBlazy P (1990) Comparison of dietary patterns between populations samples in the three French MONICA nutritional surveys. Revue D Epidemiologie et de Sante Publique 38, 517523.

Mangels AR, Holden JM, Beecher GR, Forman MR \& Lanza E (1993) Carotenoid content of fruits and vegetables: an evaluation of analytical data. Journal of the American Dietetic Association 93, 284-296.

Margetts BM \& Jackson AA (1996) The determinants of plasma $\beta$-carotene: interaction between smoking and other lifestyle factors. European Journal of Clinical Nutrition 50, 236-238.

McClean R, McCrum E, Scally G, McMaster D, Patterson C, Jackson N \& Evans A (1990) Dietary patterns in the Belfast MONICA project. Proceedings of the Nutrition Society 49, 297-305.

Ministry of Agriculture Fisheries and Food (1993) Food Portion Sizes. London: HMSO.

Ocke MC, Bueno de Mesquita HB, Goddijn HE, Jansen A, Pols MA, van Staveren WA \& Kromhout D (1997) The Dutch EPIC food frequency questionnaire. 1. Description of the questionnaire, and relative validity and reproducibility for food groups. European Journal of Clinical Nutrition 26, S37-S48.

Ollilainen V, Heinonen MI, Linkola EK, Varo PT \& Koivistoinen PE (1988) Carotenoids and retinoids in Finnish foods: meat and meat products. Journal of Food Composition and Analysis 1, 178-188.

Ollilainen V, Heinonen MI, Linkola EK, Varo PT \& Koivistoinen PE (1989) Carotenoids and retinoids in Finnish foods: dairy products and eggs. Journal of Dairy Science $\mathbf{7 2}$, 2257-2265.

Olmedilla B, Granado F, Blanco I \& Rojas-Hidalgo E (1993) Quantitation of pro-vitamin A and non-provitamin A carotenoids in the fruits most commonly consumed in Spain. In Food and Cancer Prevention, pp. 141-145 [KW Waldron, IT Johnson and GR Fenwick, editors]. Cambridge: Royal Society of Chemistry.

Olmedilla B, Granado F, Gil-Martinez E \& Blanco I (1995) Freezing effect on carotenoid content in raw and cooked vegetables and fruits. The second international food database conference. Food composition Research: The Broader Context, Lahti, Finland.

Olmedilla B, Granado F, Blanco I, Gil-Martinez E \& RojasHidalgo E (1996) Contenido de carotenoides en verduras y frutas de may or consumo en Espana (Carotenoid content in fruit and vegetables most frequently consumed in Spain). Madrid: Secetaria General del Instituto Nacional de la Salud.

O'Neill ME (1997) Factors affecting carotenoid absorption and a comparative assessment of carotenoid intakes in five European countries. University of Ulster, D.Phil thesis.

O'Neill ME \& Thurnham DI (1998) Intestinal absorption of $\beta$ carotene, lycopene and lutein in men and women following a standard meal; response curves in the triglyceride-rich lipoprotein fraction. British Journal of Nutrition 79, 149-159.

Paul AA \& Southgate DAT (1994) In McCance \& Widdowson's 
The Composition of Foods, 5th Edition. Royal Society of Chemistry: Cambridge, UK.

Renaud S \& de Lorgeril M (1993) The French paradox: dietary factors and cigarette smoking-related health risks. Annals of the New York Academy of Sciences 686, 299-309.

Scott KJ, Thurnham DI, Hart DJ, Bingham SA \& Day K (1996) The correlation between the intake of lutein, lycopene and $\beta$ carotene from vegetables and fruits, and blood plasma concentrations in a group of women aged 50-65 years in the UK. British Journal of Nutrition 75, 409-418.

Seddon JM, Ajani UA, Sperduto RD, Hiller R, Blair N, Burton TC, Farber MD, Gragoudas ES, Hailer J, Miller DT, Yannuzzi LA \& Willett W (1994) Dietary carotenoids, vitamins A, C and E and advanced age-related macular degeneration. JAMA 272, 1413-1420.

Tonucci LH, Holden JM, Beecher GR, Khackik F, Davis CS \& Mulokozi G (1995) Carotenoid content of thermally processed tomato-based products. Journal of Agricultural and Food Chemistry 43, 579-586.

van het Hof KH, Tijburg LBM, Pietrzik K \& Westrate JA (1999) Influence of feeding different vegetables on plasma levels of carotenoids, folate and vitamin C. Effect of disruption of the vegetable matrix. British Journal of Nutrition 82, 203-212.

Van Rossum CTM, van de Mheen H, Witterman JCM, Grobbee E \& Machenback JP (2000) Education and nutrient intake in Dutch elderly people. The Rotterdam study. European Journal of Clinical Nutrition 54, 159-165. WHO (1990).

Vollebregt YCJ \& Feskens EJM (1993) Samenstelling van voedingsmiddelentabellen met gehalten aan retinol en bcaroteen, vitamin $\mathrm{E}$ en pectine ten behove van oa de Zutphen-studie RIVM (Collection of food composition tables with content of retinol, beta-carotene, vitamin $\mathrm{E}$ and pectin and other uses in the Zutphen study). Report no. 441111-441002.

World Health Organization (1990) Diet nutrition and prevention of chronic diseases WHO Technical Report Series 797. Geneva: World Health Organization.

Willett WC, Sampson L, Brown ML, Stampfer MJ, Rosner B, Hennekens CH \& Speizer FE (1988) The use of a selfadministered questionnaire to assess diet four years in the past. American Journal of Epidemiology 127, 188-199.

Ziegler RG (1989) A review of epidemiological evidence that carotenoids reduce the risk of cancer. Journal of Nutrition 119, $116-122$. 